Lithic agency, Scottish modernism, and the politics of nuclear war

Michael Gardiner and Andrew Stones

Department of English and Comparative Literary Studies, University of Warwick, Coventry, $U K$

m.gardiner@warwick.ac.uk

Word Count: 7991 


\section{Lithic agency, Scottish modernism, and the politics of nuclear war}

This paper argues that entangledness with inorganic agency, particularly that of stone, not only speaks to recent object-oriented and ecocritical thought, but also marks a constitutional division within the UK, since 'thing power' implies a scepticism over the organic authority of an uncodified British constitution. The agency of stone undercuts the organicism of Hanoverian 'natural law' that can only understand the social as an 'evolving' association of individual property owners, demanding an ontological 'distance' from objects. Lithic agency was already of concern to 1920s-'30s Scottish modernists, notably Hugh MacDiarmid, but can be traced forward to anxieties over the 'totalising' or 'time-fixing' qualities of nuclear weapons. We describe this line of agential stone from modernism to the nuclear dramas of the 'New Cold War' era, and how it entails an ontological shattering of the British distance from objects. Depictions of the physical violence of nuclear standoff shatter the totalisation required by British natural law, pointing to a specifically Scottish and sub-British political aesthetic. An ontological division over nuclear weapons remains central to Scottish independence campaigns today - and their release of 'stony' and 'dusty' powers beyond the human provide a 'concrete' example for object-oriented thinking within literary theory after its geological turn.

Keywords: Stone, object-oriented ontology, Scottish modernism, nuclear, Hugh MacDiarmid, cold war.

\section{Correlationism and British Authority}

An inorganic turn in cultural theory, seen in books including Jeffrey Jerome Cohen's Stone: An Ecology of the Inhuman (2015) and Timothy Morton's Realist Magic: Objects, Ontology, Causality (2013), has sometimes described stone's ability to suggest a radically different time. Lithic time has been understood, to an extent, as interrupting the ideas of organic community that originate in Enlightenment 
conceptions of nature. ${ }^{1}$ This paper attempts to redirect this interest in stone in two ways. Firstly, if agential stone interrupts an organic understanding of the social which is based in the fixed or eternal primacy of human subjectivity, this has a particular valency for the uncodified British constitution - and, by extension, the Anglophone empire. Since-Because the modern British tradition of Britishnatural law ${ }_{2}$ made-a foundation of state and extended into empire through the long eighteenth century, understood individual property as the force of nature, the return of the inorganic forces, or 'thingly power' ${ }_{2}-$ meant a particular and direct threat. Secondly and relatedly, since inorganic agency has been constitutionally specific in this way, it has been picked up at sub-British levels. ${ }^{2}$ In particular, lithic entanglement was registered in Scottish modernism between the world wars, and then reappeared on a wider level after the attrition of post-war consensus in the 1970s and ' 80 s. In turn, an attempt to stabilise objects relative to individual ownership can be read in the Thatcherite commitment to nuclear weapons - while conversely nuclear war docudramas track Scottish modernism's attitude to object entanglement. The idea that nature exists 'for us' has been a pillar of British liberalism and neoliberalism, and this became an underground ontological issue in the 2014 Scottish independence referendum, when it already had this long history of lithic entanglement behind it.

Quentin Meillasoux's term correlationism is probably most familiarly associated with Kant's preface to the Critique of Pure Reason, in which he formalises the relation between human and non-human natures:

it has been assumed that all our cognition must conform to the objects; but all attempts to find something about them a priori through concepts that would extend our cognition have [...] come to nothing. Hence let us once try whether we do not get farther with the problems of metaphysics by assuming that the objects must conform to our cognition,... which is to establish something about objects before they are given to us. ${ }^{3}$

This means that, firstly, we can only think objects as they appear to us - objects conform to our minds - and secondly, there can be no knowledge of being-in-itself outside of these objects' appearances. What exists outside of the world as-it-appearsto-us, Kant called the noumenal, as opposed to the phenomenal - but continental philosophy has recently enhanced the standing of the latter. Under correlationism, 
'[n]ot only does it become necessary to insist that we never grasp an object 'in itself', in isolation from its relation to the subject, but it also becomes necessary to maintain that we can never grasp a subject that would not always-already be related to an object' ${ }^{4}$ However, since the early 2000s a theme of object-oriented or speculative realist has been a scepticism towards Kant's epistemological bind as described by Meillassoux, because 'we only ever have access to the correlation between thinking and being, and never to either term considered apart from the other'. ${ }^{5}$

But despite the unusual association of correlationism with Kant, the primacy of the subject which stands over and regulates the noumenal as its appearance to us can be traced back and strongly linked to the establishment of the modern British state in a trajectory that runs from John Locke through David Hume to Edmund Burke. The philosophical underpinnings of the Hanoverian Restoration of 1688 anchored organic ideas of government in a powerful tradition of natural law that would increasingly drawing from the universal laws of Newtonian cosmology and stressing a world of discrete and ownable objects. Where the expansion of property ownership is a natural condition of the social, or for Locke '[t]he great and chief end... of Men's... putting themselves under Governments', ean-the stakes of correlationism are particularly high, and are become the basis of a whole lifeworld. ${ }^{6}$ Locke's insistence on citizens' relation to property demands-means both that the labouring body itself must have already been owned, and that the property-owning individual, now the natural basis of social organisation, depends on the object-in-itself's inertness and passivity. ${ }^{7}$ So if correlationism was important to Kant, for the modern British state it was already not only important, but a condition of existence. This foundational correlationism says much about the peculiar homeliness of the neoliberal extension of possibilities for property in Britain, and about what William Davies has described as an undeclared reliance on a 'metaphysics' of the individual. ${ }^{8}$

A Lockean or Hanoverian correlationist This tradition of natural law would be accepted built on and transmitted in various forms by most of the literati of the Scottish Enlightenment, in particular after the quelling of the Jacobite rebellions of the 1740s, and indeed the evolution of property forms would be made an overarching historiographical principle by Adam Smith's Lectures on Jurisprudence (1763) and these by many theories of history who followedto follow. ${ }^{9}$ David Hume's Enquiry Concerning Human Understanding (1748) discourages speculation about objects, 
since "nature... has afforded us only the knowledge of a few superficial qualities of objects', and that we can only have knowledge of those objective qualities which are made to conform to our senses. ${ }^{10}$ Ontology then is less a question of 'being' than of 'being-for-us' - knowledge of the object can only occur in the presence of a corresponding subject. Although it often referencesing Kant, this ultimately is what was taken issue with by 2000s object-oriented ontology, not whether the object is knowable per se, but whether there can only be knowledge of the object when a subject is present. The empiricism of Locke and Hume - or- Hanoverian empiricism is firmly rooted to human perception - so '[o]ur senses inform us of the colour, weight, and consistency of bread; but neither sense nor reason can ever inform us of those qualities which fit it for the nourishment and support of the human body'.11 Distant nature is only palatable in so much as it resembles our insides - and the whole world becomes food for thought.

By the time of Edmund Burke's 1790 critique of revolutionary action, nature has become the organic continuity of habits and impressions experienced by a transcendental subject - and a Gothic imagery of humans' (and Humeans') coming face to face with an inorganic agency will put this continuity into crisis. Nature is now, in a specifically British sense, understood as the reduction of objects to a relationship of possession, and

[b]y a constitutional policy, working after the pattern of nature, we receive, we hold, we transmit our government and our privileges in the same manner in which we enjoy and transmit our property and our lives... Our political system is placed in a just correspondence and symmetry with the order of the world and with the mode of existence decreed to a permanent body composed of transitory parts... ${ }^{12}$

But if the correlationist relationship to property in this long eighteenth century trajectory had been working towards an ethics of imperial expansion, this would be shaken by the catastrophic failure of the trading empires arising from this expansion of trading empiresfrom the end of the next century, and made concrete in World War One. Scottish modernist writers especially in particular show tendencies that resonate with later object-oriented thinking's attempts to overcome correlationism, and with the inorganic stresses of continental philosophy. Levi Bryant captures the urgency of 
this turn when he argues that 'the broader strategic import of the concept of [objectoriented] ontology is to diminish the obsessive focus on the human, subjective and the cultural within social, political, cultural theory and philosophy'. ${ }^{13}$ A recent 'lithic turn' can be seen relative to a much longer refusal of the subject-object or humannature relation that was foundational to British capitalism (or Britain-as-capitalism). As in Jane Bennett's catalogue of materialist philosophers (Democritus, Epicurus, Spinoza, Diderot and Deleuze) who attempted to 'think' the agency or 'thingly power' of the object before it becomes an Other-opposite-me, we suggest that there is a politico-aesthetic refusal of British 'constitutional nature' in some Scottish modernism, which in turn looks forward to the urgency of 'object entanglement' in depictions of nuclear war. ${ }^{14}$ The 'object-oriented' turn at the turn of the twenty-first century is, in that sense, a re-turn to the modernist fissure with Burkean nature from the early twentieth - where an entanglement with the inorganic is 'felt' at once as a constitutional rupture with British natural law and a wider ontological rupture.

\section{The Fissure: Scottish Modernism}

Scotland has long been a sticky area for British natural law. If in the eighteenth century urban Scottish ideas were crucial to extending the property-owning subject through empire, there would later be a strong swing away from these correlationist demands - understood, especially after World War One, as nationally specific. By the start of the nineteenth century, an Edinburgh geology boom spurred by James Hutton and his followers had struggled to square a world made for humans with chronologies beyond human measure - today understood more generically as deep time - and the conclusion that "with respect to human observation, this world has neither a beginning nor an end'. ${ }^{15}$ As Stephen Jay Gould has glossed the Edinburgh geology boom, '[b]y recognizing the igneous character of many rocks previously viewed as sediments (product of decay), Hutton incorporated a concept of repair into geological history. If uplift can restore an eroded topography, then geological processes set no limit upon time'. ${ }^{16}$ Human understandings of continuity and stasis, that is, become inadequate to earthly processes, and there appears the spectre of, as Jussi Parikka puts it, 'a radical immensity of time... imagining possible pasts and futures without humans'. ${ }^{17}$ This was, as Jeremy Davies says, 'not an arena in which stable natural processes endlessly 
reproduce themselves, but a field of action dense with contingent successes and catastrophes'. ${ }^{18}$

There are hints of such a temporality's influence on the contemporary literary imagination, Hutton's sometime Edinburgh contemporary Robert Burns for example turning to geological change to imagine the beyond of human intention - 'Till a' the seas gang dry, my dear / And rocks melt in the sun'. ${ }^{19}$ (And Gould describes the appearance of homo sapiens 'a few moments before Auld Land Syne'). ${ }^{20}$ Deep time imagery remains important for twenty-first century energy politics - Timothy Mitchell's Carbon Democracy for example, which opens with a long description of the ungraspable timescales involved in compressing organic life and rock together as oil. $^{21}$

It is this later scepticism that would point forward to Scottish modernism's turn away from Hanoverian correlationism and towards an imagery of agential stone. Something of this Scottish modernist lithic turn was recognised by Cairns Craig's mid-'90s description of the stony interests of the Scottish Renaissance (roughly from 1926 to 1935) as attempting to tackle Scotland's 'entry into history' after World War One. ${ }^{22}$ In Lewis Grassic Gibbon's A Scots Quair (1932-34), the human 'history' that takes Chris's husband into the war is dwarfed by the stone war monument and the ancient standing stones to which Chris keeps returning for temporal perspective. ${ }^{23}$ Later in the trilogy Chris's son's communist commitment is 'likened to grey granite itself', and Aberdeenshire granite, 'alive' with radioactivity, would give the last novel of the trilogy its title. ${ }^{24}$ Elements of this lithoscape are anticipated by Nan Shepherd's Grampian novels (1928-33), made into a quartet by the later addition of The Living Mountain, an ecological paean to the mountain as an organic, inorganic, and atmospheric body, whose opening might almost be paraphrasing Hutton's description of active granite - '[t]he Cairngorm Mountains are a mass of granite thrust up through the schists and gneiss that form the lower surrounding hills' - and which closes ' $[\mathrm{t}] \mathrm{o}$ know Being, this is the final grace accorded from the mountain. ${ }^{25}$ For Craig, the narrative use of mountain perspectives particularly suggest an intervention into Scotland's 'problem of a suspended history', and he cites examples from A Scots Quair to Alasdair Gray's Lanark (1981) that gesture towards a wider inorganic entanglement, or lithic yearning. ${ }^{26}$ 
Yet surely the most iconic example of this lithic yearning is Hugh MacDiarmid's poem 'On a Raised Beach', from his 1934 book Stony Limits (a phrase repeated apparently unwittingly by Cohen's Stone (2015), in which a failure to perceive the 'openness and indeterminacy' of life in granite represents a 'stony limit'). ${ }^{27}$ Stony Limits has sometimes been seen as marking the point at which a MacDiarmid in poor nervous health, and disspirited at an early lack of mainstream success, sought solace in the bleaker environment of Shetland (and indeed around this point he rehabilitated at the Perthshire psychiatric hospital called Gilgal - 'circle of sacred stones'). ${ }^{28}$ The same year MacDiarmid was the dedicatee of Gibbon's Grey Granite, and Louisa Gairn rightly points out a 'geological' terminology in Gibbon's subtitles. $^{29}$ 'On a Raised Beach' places a lone narrator on an extensive rock formation understood as a source of nourishment - a 'bread from stones' countering Hume's correlationist insistence on a communion with the noumenal world. ${ }^{30}$ Stone is now life-creating, as in Cohen's etymological investigation of stone as a seed - so for MacDiarmid '[a]ll is lithogenesis - or lochia [post-partum fluid]'. ${ }^{31}$

Moreover here the organic body and the lithic body share a time - the inorganic no longer follows the owning subject, but is made simultaneous to it through touch specifically - a resolve to turn again 'From optik to haptik and like a blind man run/ My fingers over you'. ${ }^{32}$ The move from optic to haptic both problematises the empiricist arrangement of objects in space and sets up a thematics of touch as present-tense action that would look forward to the 1980s-'90s 'Second Renaissance' - the blinded narrator of James Kelman's How Late It Was, How Late (1994), for example, who remaps Glasgow by feeling his way across the stone buildings, 'the patacake games'. ${ }^{33}$ Entanglement with the inorganic eclipses the developmental temporality central to correlationism, and instead embraces what may appear deathly -

How else does any man yet participate

In the life of a stone, ...

Till as the stone that covers him he lies dumb

And the stone at the mouth of his grave is not overthrown? ${ }^{34}$

If these stones appear stark and cold, they are also '[d]eictic, fiducial', they have an 
indicative function and a 'critical' role. ${ }^{35}$ Their existence here must be mysterious the question '[w]hat bricole piled you here, stupendous cairn?' referring both to the medieval catapult and to 'bricolage', an assemblage without a unifying essence, or some non-Lockean form of 'nature' that incorporates the inorganic. ${ }^{36}$

Moreover these stones share an objective particularity, or what MacDiarmid describes as a 'haecceity' - a term taken from the medieval philosopher Duns Scotus to suggest a willed object-ness in the perception of the object. ${ }^{37}$ As MacDiarmid glosses the term later, haecceity is non-subjective and based in 'the individuality of elements in a particular context' - or elsewhere, - 'what [G.M. Hopkins] following Duns Scotus, called haeccitas, the 'thisness' and individuating reality of things' ${ }^{38}$ Individuation in this context refers to a process of morphogenesis in the world of which human subjectivity is only a secondary effect - and MacDiarmid's use of the term bears an uncanny resemblance to its use in Deleuze and Guattari's A Thousand Plateaus, itself an important touchstone for object-oriented thinkers (and whose takeup of Scotus's term is probably often imagined to be unique). ${ }^{39}$ Both MacDiarmid and Deleuze and Guattari adapt Scotus's term in the geological sense of intensive processes producing emergent properties. The haecceity is also 'me' - I am my intensities - and relations between subjects are a specific kind of relation between pre-personal processes which encompass partial objects, body parts, and material flows. ${ }^{40}$ Perception is being rethought as a property of the world rather than something humans simply 'do' - so stones' 'inner' gates are 'open wider' than those of humans or even animals - they are free of the 'fleeting deceit of development'. ${ }^{41}$ Thus the rejection of correlationism stated more starkly here:

What happens to us

Is irrelevant to the world's geology

But what happens to the world's geology

Is not irrelevant to us.

We must reconcile ourselves to the stones,

Not the stones to us. ${ }^{42}$

Like the Demosthenean pebble placed in the mouths of Greek orators to overcome speech impediments, these agential stones force an acknowledgment of materiality - 
or radically expose the cogito to its own objectivity. ${ }^{43}$ This counter-correlationist reconciliation of stone would remain important to Scottish considerations of the subBritish national - Neal Ascherson's Stone Voices (2002) for example, a journey through through ancient stone monuments and Hutton's Edinburgh, starts with an epigram from 'On a Raised Beach', and tracks stones' inner gates' onto an understanding of the national image. ${ }^{44}$ Twentieth-century Scottish writing would often return to lithic agency in this sense. George Mackay Brown described the timehaunted islands of an Orkney marked with stone circles. ${ }^{45}$ And Edwin Morgan's Sonnets from Scotland recalls both MacDiarmid's inorganic 'national' landmass and the lithoscape of nuclear war-

We saw Lewis

laid down, when there was not much but thunder and volcanic fires...

Memory of men! That was to come. Great in their empty hunger these surroundings threw walls to the sky, the sorry glory of a rainbow. Their heels kicked flint, chalk, slate. $^{46}$

This sequence moves to a nuclear strike and the humans who become meat in a geological sandwich -

... running with fire in their hair,...

Ovens of death were falling from the air.

Lucky seemed those at the heart of the blast, who left no flesh or ash or blood or bone, only a shadow on dead Glasgow's stone. ${ }^{47}$

It is probably well known that Morgan's work both acted as a conduit for a vast range of European modernisms, and was associated with devolution and independence issues, with his commissioned poem performed, for example, at the opening of the Scottish Parliament in 1999. Again apparently accidentally, Cohen notes that the Museum of Scotland - reopened in 1998 between the devolution vote and its enactment - narrates Scotland's history exactly as in Morgan's timescale in 'Slate', 
beginning with geological formation, and only later incorporating human settlement. ${ }^{48}$ And if this temporal shift does suggest a move from the subject-centring crucial to the unwritten British constitution, it was becoming more pronounced at the time of Morgan's sequence with the totalisation, or de-materialisation, of violence particular to nuclear weapons.

\section{Nuclear War Docudramas as Lithic Narratives}

Most of the recent accounts of the cultures of 1980s nuclear terror begin from around NATO's deployment of Cruise and Pershing II in western Europe in 1979 - which, as Daniel Cordle puts it, 'made the possibility of nuclear war both more visible and more likely'. ${ }^{49}$ This dating is fine, but the importance of nuclear weapons to the British (military) theatre might also be described in terms of a reassertion, for an era of neoliberalism, of the correlationist veto on object entanglement. It would help to understand Thatcherism's drive to restore the individual subjectivity defined by property ownership, and its determination to hold back the creeping inorganic temporalities increasingly visible in popular culture, and often vested in stone. Stone circles appear frequently in the sub-genre now sometimes called Folk Horror, suggesting pre-modern - pre-Hanoverian - powers, and they address a generation growing up after the memory of the war's mass defence of the organic. The Changes (1975), based on Peter Dickinson's Weathermonger trilogy (1968-70), imagines a sudden mass fear of technology that sends wandering children out to consult an Arthurian megalith about the balance of nature. ${ }^{50}$ Stone circles often signal timetravel, or as Cohen puts it, they frustrate anthropocentric continuity by creating 'a lived space where a present mobilizes a past'. ${ }^{51}$ In $S k y$ (1975), a child from a far future seeks out Stonehenge, through which to return his own time, in which a weird religious ceremony commemorates the catastrophes of anthropocentrism. ${ }^{52}$ In Children of the Stones (1977) stone circles generate a time-slip trapping the protagonists. ${ }^{53}$ And in Quatermass (1979), bands of kids stream along ley lines to stone circles acting as a secret conduit. ${ }^{54}$ In all these popular dramas, just as in 'On a Raised Beach', stone is able to trigger another possible temporality. And against this threat of non-correlationist time, nuclear violence would act as a temporal 
redisciplining, by presenting a form of violence that is continuous and, as neoliberalism would increasingly demand, immaterial. Or more simply, nuclear violence is a perpetual delay of materiality. It is the form of coercion most fitted to the insistence on a correlationist world. ${ }^{55}$

Never part of any 'physical' war, these weapons are nevertheless constantly in use, working for the unearthly reconciliation of mass destruction and the neutral rule of law. But against this demand, depictions of nuclear war, or the aesthetics of what we have called Nuclear Gothic, return the spectre of uncontrolled materiality. ${ }^{56}$ Nuclear Gothic calls the bluff of Burkean claims to neutrality, and reveals the politically contingent and synthetic within the organic and the eternal. Like post-1789 Gothic fiction, Nuclear Gothic is a constitutional critique of organic authority - and like 'On a Raised Beach', it shifts agency from the human to the lithic.

Moreover Nuclear Gothic tends to do this from a generic position that places an additional stress on fictionalisation that attenuates the 'realism' of civil defence. As Duncan Campbell points out in War Plan UK (1983), the emergency powers granted to the government during the New (post-1979) Cold War are grounded not in escape but in stasis - '[i]n Britain, the idea of civil defence has been turned on its head. The official policy which is more concretely styled "Home Defence", has, as its primary objective, the preservation of government - if need be, against the civil population. ${ }^{57}$ This gives nuclear civil defence an odd sense of empty defence, especially after the notorious Protect and Survive campaign (1980). Mick Jackson's QED: A Guide to Armageddon places three couples at various distances from an airburst over St. Paul's to follow civil defence guidelines to their inevitable awful fates. ${ }^{58}$ Jackson followed this with the extraordinarily impactful feature-length drama Threads (1984), which builds on research contravening Home Office figures based on the 1980 NATO operation Square Leg, and draws on the mix of fact, drama, and real interview in Peter Watkins's The War Game (1965), kept from domestic audiences until 1985, 'ostensibly because it was "too shocking" to be shown on television, although there was clearly also a concern that it made CND's case too well'. ${ }^{59}$ The War Game pointedly stretches the defence of the British organic familiar from World War Two, particularly Humphrey Jennings's Fires Were Started (1943) - its firestorm in Rochester, for one thing, which now can't be stopped by any emergency service. ${ }^{60}$ Particularly in this adaptation there is a recognition that nuclear violence is neither realist nor simply non-fictional, but instead demands a weird kind of alternate history 
with no equivalent in the liberal temporality of development. This docudrama form is not merely the time of speculative fiction, but is beyond developmental time altogether. As Cordle points out, the documentary-realist features of Threads are particularly peculiar in this sense, since the film is looking back from a time when it argues that no such film-making technology would exist. ${ }^{61}$

And as well as paradoxically assuming the failure of Mutually Assured Destruction, civil defence is seen in the docudramas to over-rely on the world of the discrete individual, which drastically underestimates the interconnectedness of life support systems. When Tory MPs argued in 1980 that effective civil defence could reduce deaths to 20 million, they were still disregarding the knock-on effects of the failures of collective provision. ${ }^{62}$ The strategic move to Launch on Warning similarly attenuated the individual subject supposedly defended, since it removed judgment entirely. As some of these docudramas understand, the basis of the social in propertyowning individuals of course also seriously attenuates the communal desire to pull together that can be drawn on by films like Fires Were Started - and this individualism is itself undermined by the stress on interconnectedness framing $Q E D$ and Threads ('in an urban society everything connects. Each person's needs are fed by the skills of many others. Our lives are woven together by a fabric. But the connections that make society strong also make it vulnerable'). ${ }^{63}$

It is in Threads that the realism that had stood behind the anthropocentric narrative become obviously mutated, significantly in a script by Barry Hines whose $A$ Kestrel for a Knave (1968) had been reworked as Ken Loach's social realist classic Kes (1969). Threads begins with the class observations typical to of the '60s mode of social realist film, as middle-class Ruth becomes pregnant by her working-class boyfriend Jimmy, the families meet awkwardly, Jimmy's father's redundancy money is used for a deposit for a flat, and there are hints of Jimmy's infidelity. After the blast, however, these half-developed realist problems and characters do not fizzle out, they simply fall out of the narrative. Jimmy's father is one of the few characters with an ongoing story, but he will soon die against a gravestone, recalling Chris's encounter with the village monument in A Scots Quair, but others are simply no longer seen. Expectations of subject-centred realist narratives disappear, and stone reasserts itself.

So concrete - the promise of the malleability of stone to extend the realm of human home that characterised the post-war consensus - does not so much crack or 
collapse in the blast as explode. In the rubble of houses left open to the sky, it becomes obvious not only that protection from buildings has been overestimated, but also that determination may have passed back to self-assembling stone with a sense of inevitability - or as 'On a Raised Beach' had put it, '[t]here are plenty of ruined buildings but no ruined stones' ${ }^{64}$ Within days the rubble of homes and businesses has re-formed into new and apparently permanent routes, which pile up and have to be navigated by wanderers and scuttling children, who, unlike those of post-war bombed-out London, will not be able to rebuild. ${ }^{65}$ When the pregnant Ruth makes her way outside, the timescale of civil defence (fourteen days beneath a leaning door), social realism, and human intention in general, no longer inhere.

Threads then might be seen as a story of a failure of the world of things-forus, as the nuclear blast disperses organic and inorganic materials to become agential in one form as fallout dust, radically disassembled matter, stone, earth, animals and plants, which will combine with the bodies of survivors. Fallout dust is Gothic matter, dispersing a time beyond human death throughout the spaces of continuous empty time, and forming what Steven Connor has described as 'a temporal, even a temporised and temporising kind of matter... pure, or perhaps rather, impure, matter... the matrix or negative of form' ${ }^{66}$ Or as Parikka describes, dust is:

[not] quite of the ground, not quite the atmosphere... Nanoparticles are everywhere and form societies unseen and unheard of, yet they conglomerate on a scale unimaginable to human beings... Dust forms geological strata. Dust marks the temporality of matter, a processual materiality of piling up, sedimenting, and - through its own million-year process - transformations of solids to ephemeral and back... Dust does not stay outside us but is a narrative that enters us... ${ }^{67}$

The agency of fallout dust indeed was a serious topic in the early ' 80 s in debates over the likelihood of a 'nuclear winter', a shroud of particles making life on earth unsustainable. ${ }^{68}$ One scientific account from 1982 suggests that fallout warps the timescales of existing estimations of damage:

Extremely small particles with diameters of a few hundred-thousandths of an inch can remain suspended in the atmosphere for several years. During this 
period the dust can be blown many times round the world by strong winds in the upper atmosphere. ${ }^{69}$

If dust is 'matter in the wrong place', a world shrouded in agential fallout dust is matter threatening to slip out of human use altogether. ${ }^{70} \mathrm{~A}$ world-without-us, or what Eugene Thacker has termed, 'a mysticism of the unhuman', 'can only be expressed in the dust of this planet' ${ }^{71}$ Threads gives its narrative to the deep time of fallout dust from the first clouds about which the wartime controller has to appear stoical although he knows they're killing his wife, to the masses of irradiated crumbling bodies. As the story moves on over a decade, human timescales slide away and 'population declines, perhaps to medieval levels', masked figures silently hoe the dead earth, and the scene is described by interspersed black and white pictures of broken masonry, as at the silent conclusion of the 1982 QED.

Radioactive 'Gothic matter' also concerns another pioneering documentary form in Troy Kennedy Martin's 1985 series Edge of Darkness, a noir thriller complicated by various levels of facticity including public figures playing themselves (the left-wing Labour MP Michael Meacher and the TV presenter Sue Cook serving as a kind of fiction-framed authentication) and the storage of plutonium deep under rock in a disused coal mine referencing the energy battles of the recently ended miners' strike. ${ }^{72}$ If Threads is a speculative fiction framed by factual information the documentary mode precedes Jimmy and Ruth's social-realist look out over Sheffield -Edge of Darkness is based in a heavy research into 'a country moving remorselessly towards a nuclear state, with all that meant for the loss of civil liberties', but is framed by anti-naturalism, in the supernatural presence of the detective's dead daughter. ${ }^{73}$ Riding on a new 'literariness' coming with the move from the single drama (Play for Today, The Wednesday Play) to the drama series, Martin was able to unfold a longstanding scepticism over progressive-naturalist narratives to create what has been called a 'paranoid fiction', one able to 'get away with visions that under other circumstances (e.g. documentary or current affairs) wouldn't make it to the screen... [and] unravel some of the complexities of public life more truthfully than investigative journalism'. ${ }^{74}$

Here gestures towards lithic time appear as soon as the young activist Emma is shot dead near the start of the first episode, to reappear in spectral form beside her father, who from near the start embodies a being-towards-death that is only confirmed 
by his later radiation sickness (and is guided by the MacDiarmid-like motif of the black mountain flower that inherits life after humanity). This relation shows something of the generational anxiety of Kelman's ' 'My Eldest', whose narrator stares towards the nuclear base at Holy Loch, jokes about sitting on a Trident submarine, and tries to reach his inexplicably tense son running across the stony beach. ${ }^{75}$ In Edge of Darkness it soon becomes clear that Emma's non-correlationist political life, in a deep ecology group gesturing to the 1979 ideas of James Lovelock, is reorienting the story towards a geological timescale - 'man is the enemy, [the earth] will destroy him'. ${ }^{76}$ The drama then is flooded with a beyond-death that frustrates assumptions about the 'usefulness' of nuclear materials and drives Craven towards his eventual alliance with stone. This derailing of human developmental narratives, in the death of the child before the parent and in a wider 'geologising' of experience, is set against two lithoscapes that have the potential to disturb timescales - the mine with its catastrophic plutonium half-lives and its forgotten nuclear bunker, and, confirming national fissures within the correlationist world, the Scottish mountains. Where for Burke nature had been 'radiant' and reflected 'English civilization' back onto itself, the world of Edge of Darkness is unreflective, dull, opaque, and 'withdraws' from the visual faculties in the way described by some object-oriented philosophers, at the limits between phenomena and noumena. ${ }^{77}$

For Craven will travel north of the border in a journey that echoes Mary Shelley's Frankenstein. At Gleneagles Craven's CIA acquaintance Jedburgh watches the nuclear entrepreneur Grogan describe how plutonium will be used to colonise space so that 'man will be in charge' - but this is undermined by Jedburgh's knowledge that plutonium is in the room, and punctuated by Craven's own vomiting. ${ }^{78}$ Plutonium, generator of energy and Gothic matter, turns out to be difficult to 'own' - it undermines the property relation that stabilises the subject in the British social - it refuses to stay at a stable correlationist distance. Plutonium, as it happens, is one of Timothy Morton's examples of a hyperobject - it is 'sticky', attaching to those near it, it is nonlocal, it 'involve[s] profoundly different temporalities than the human-scale ones', and despite its agency, it is 'invisible to humans for stretches of time'. ${ }^{79}$ In Edge of Darkness similarly, the movement of the plutonium drives a narrative dissipated in time and space, whose 'paranoia' suggests a 'messy' nonHumean causality. 
Jonathan Schell's The Fate of the Earth (1982) had already popularly described how if nuclear war and nuclear winter could threaten the existence of all life on earth, then nuclear violence is already eviscerating human developmental narratives - creating a pure continuity, or death of death, forcing us to acknowledge a world that has never been for human time. ${ }^{80}$ In a nuclear-themed 1984 issue of Diacritics, Frances Ferguson anticipates Troy Kennedy Martin's Frankensteinian journey to bleak Scottish rock by describing Schell's nuclear annihilation as sublime, a submission to something immeasurably great, and here paradoxically beyond material violence in a totalisation of correlationist natural law, 'a world in which the status of objects is progressively attenuated so as to suggest that it is subjectivity rather than the mere fact of the existence of objects that gives things their force' ${ }^{81}$

Edge of Darkness is this kind of Gothic journey north into unthinkability, and it takes place within a geographic centre of pessimism over the representative power of the British state. In the much-discussed closing sequence Craven becomes the mountain - as the plutonium is recovered from the bottom of Loch Lednock, the camera turns to see him standing on the darkening mountain in a shot containing only him, sky, and rock. (The original script had suggested Craven becoming a tree as in 'Green Man' imagery, but accompanied by thunder - etymologically tied by Cohen to toner, a-ston-ishment). ${ }^{82}$ And crucially in this lithic becoming Craven registers not only an anti-correlationist point, but also, on a stage much like MacDiarmid's, a constitutional point. Moreover the view that looks back down the mountain strongly recalls the 'nuclear glen' image now common in documentaries and news and tying together images of nuclear weapons and images of nuclear protest. The view down the glen, towards the nuclear facility, real or implied, was by now a visual shorthand both for nuclear issues and for direct action, that is, refusal of British representation and indeed Emma's 'Gaia' activism confirms the knit of anti-nuclear activism and direct action. This lithosphere is tracked by Duncan Campbell's 1987 BBC2 investigative journalism series Secret Society, which describes the sweeping powers granted in a nuclear crisis, in which an aerial shot of the walk 'from Loch Lomond to Loch Long' is backed by the folk song by Dick Gaughan that sees the weapons appear in 'man-made caverns flanked the hills/ Caverns grim of concrete grey'. ${ }^{83}$ To contemporary viewers Craven's becoming-stone already suggests this constitutional challenge - it links national action to the possibility of circumventing the correlationist commitment to 'total' violence. 


\section{Stony Landscapes and Constitutional Ravines}

This historical enmeshing of an ontological and a constitutional standoff remains crucial. Nuclear ontology, along with nuclear weapons, was one of the key fissures behind the 2014 Scottish independence referendum - though most such fundamental divisons were fairly successfully reduced to empirical or psephological concerns in the London media (fear of economic instability, rational choice in voting). We have suggested that the materiality of nuclear war in post-1979 culture is thematically bound up with a 'stony' consciousness that is sceptical about the totalisation or dematerialisation of violence - but that in this it continues Scottish modernism's lithic yearnings. We have also suggested that this 'total' violence is an avoidance of objectentanglement, and that Nuclear Gothic docudramas in-disrupt this avoidance through a 'stony' form. The national specificity of anti-nuclear action was recognised by the wave of small literary-political magazines growing in what seemed the darkest hour of democratic deficit (Cencrastus, Chapman, Radical Scotland), in which unilateralism is strongly linked to (pre-New Labour) campaigns for devolution and independence.

Indeed since all major Westminster political parties gave up on the possibility of unilateral disarmament in 1983, 'nuclear correlationism' has been bound together with British-realist parliamentary representation. As recently as 1982, nuclear protesters were able to postpone for two years the ironically named military exercise Hard Rock, but as UK-level politics itself became more individualised, concentrating on identity politics or the equivalence of market actors, the threat of nuclear extinction became an odd British blindspot only widely interrogated again with 2010s debates over Scottish independence. Scottish independence and disarmament questions have remained fundamentally linked all the way through 2014, and nuclear weapons as the correlate of the 'owning' of nature, as we have suggested, are crucial to a British lifeworld — which helps explain the relative disinterest in making a case for them on the part of No campaigners.

So although recently both ecocritical and object-oriented thought have recognised that the discrete subject standing over and apart from objects is environmentally catastrophic, what have remained less appreciated are this subject's constitutional fix, and the readability of this constitutional fix in nuclear dramas. ${ }^{84}$ 
The appearance of agential stone in high modernism signalled a threat to mythologies of anthropocentric continuity and their correlate in the British state's idea of nature, an idea commensurate with, and coming to demand, nuclear terror. Since 1979 nuclear disarmament has had markedly less support in Scotland than in the rest of the $\mathrm{UK}$, and this is only problematically describable in terms of the country being 'further left' (or in terms of the SNP as the 'conscience of the Labour Party') - more fundamentally there is an ontological unevenness which becomes unsupportable in the face of correlationism under post-1979 neoliberalism. ${ }^{85}$

In this context, the turn towards objects, either in the form of object-oriented ontologies (Bryant, Harman, Morton), or of 'vital materialism' (Bennett), or of 'speculative realism' (Meillassoux) is directly appropriate to thinking about subBritish cultures of dissent. Especially since the correlationism Meillassoux diagnoses as a Kantian malady has always been an existential condition for a Hanoverian constitution that rested 'naturally' on property and was able to spread capitalist principles of accumulation throughout the empire, this unexpectedly long history of lithic encounters suggests the paving of a way to a social less slavishly bound to ownership.

\footnotetext{
${ }^{1}$ This understanding of nature resonates to an extent with current descriptions by Jason Moore and others of the capitalist capture of nature, so that the social emerges out of nature and intervenes in it from without, making capitalism not merely an economic system but also 'a way of organizing nature', Moore, Jason W, Capitalism in the Web of Life: Ecology and the Accumulation of Capital. London: Verso 2015, 2.

${ }^{2}$ By 'democratic deficit' we refer to the perceived gap between lived experience and political representation, usually associated with the period after the 1979 Scottish independence referendum, but attributable to UK-wide issues.

${ }^{3}$ Immanuel Kant, The Critique of Pure Reason. Trans. Paul Guyer and Allen W. Wood. Cambridge: CUP 1998 (1781), 110.

${ }^{4}$ Ibid.

${ }^{5}$ Quentin Meillassoux, After Finitude: An Essay on The Necessity of Contingency. London: Continuum 2009 (2006), 5.

${ }^{6}$ John Locke, Two Treatises of Government. Cambridge: CUP, 2010 (1689), 350.

${ }^{7}$ Locke, Two Treatises of Government, 288.

${ }^{8}$ William Davies, The Limits of Neoliberalism. London: Sage, 2014, 15.
} 
${ }^{9}$ Adam Smith, Lectures on Jurisprudence. Oxford: Clarendon, 1978 (1763), 14-37.

${ }^{10}$ David Hume, An Inquiry Concerning Human Understanding. Oxford: Oxford University Press 2007 (1740). 24.

${ }^{11}$ Hume, An Inquiry Concerning Human Understanding, 114.

${ }^{12}$ Edmund Burke, Reflections on the Revolution in France. London: Penguin, 1986 (1790), 120.

${ }^{13}$ Levi R. Bryant, The Democracy of Objects. Ann Arbor: Open Humanities Press 2011, 247.

${ }^{14}$ Jane Bennett, Vibrant Matter: A Political Ecology of Things. North Carolina: Duke University Press, 2010, xiii - 'there is also a public value in following the scent of a nonhuman, thingly power, the material agency of natural bodies and technological artefacts.' ${ }^{15}$ James Hutton, Abstract of a Dissertation ... Concerning the System of the Earth, its Duration, and Stability. Edinburgh: Scottish Academic Press, 1987 (1785); on Hutton, anthropocentrism, and granite cf. Alexander Broadie, The Scottish Enlightenment: Collected Writing (Edinburgh: Canongate, 2011), 214; Stephen Jay Gould, Time's Arrow: Myth and Metaphor in the Discovery of Geological Time. Cambridge MA: Harvard UP, 1987, 6, 63, 129

${ }^{16}$ Gould, Time's Arrow, 64, 65.

${ }^{17}$ Jussi Parikka, A Geology of Media. Minneapolis MN: University of Minnesota Press, 117, 37-39; cf. Gould, Time's Arrow, 104, 123. The idea of the 'deep time' of media makes Hutton an unlikely ally of the 'non-human turn' in recent object-oriented and 'speculative realist' thought (c.f Steven Shaviro, The Universe of Things. Minneapolis MN: University of Minnesota Press 2014; Graham Harman, Towards Speculative Realism. Alresford: Zer0 2010. ${ }^{18}$ Jeremy Davies, The Birth of the Anthropocene. Oakland CA: University of California Press, 2006, 26.

${ }^{19}$ Robert Burns, 'A Red Red Rose', in Selected Poems. London: Penguin, 1993 (1794), 178.

${ }^{20}$ Gould, Time's Arrow, 3.

${ }^{21}$ Timothy Mitchell, Carbon Democracy. London: Verso, 2013 (2011)), 12-15.

${ }^{22}$ Cairns Craig, Out of History: Narrative Paradigms in Scottish and British Culture.

Edinburgh: Polygon, 1996.

${ }^{23}$ e.g. Sunset Song, in A Scots Quair. Edinburgh. Canongate, 1995, 40-41.

${ }^{24}$ Gibbon, Grey Granite, in A Scots Quair, 164. (Pagination is of each novel).

${ }^{25}$ Nan Shepherd, The Living Mountain. Edinburgh: Canongate, 2011 (1977, composed 1940s), 1, 108; Shepherd. The Grampian Quartet. Edinburgh: Canongate, 2011 (1928-33); on 'provincial' modernism, cf. Robert Crawford, Devolving English Literature. Edinburgh.

Edinburgh University Press, 2002 (1992), 216-270.

${ }^{26}$ Craig, Out of History, 48-50, 57, 53. 
${ }^{27}$ Hugh MacDiarmid, 'On a Raised Beach'; on life in granite cf. Jeffrey Jerome Cohen, Stone: An Ecology of the Inhuman. Minneapolis: University of Minnesota Press, 2015, 6. ${ }^{28}$ Scott Lyall, Hugh Macdiarmid's Poetry and Politics of Place: Imagining a Scottish Republic. Edinburgh: Edinburgh University Press 2006, 120.

${ }^{29}$ Louisa Gairn, Ecology and Modern Scottish Literature. Edinburgh. EUP, 2008, 103-04.

${ }^{30}$ MacDiarmid had contact with members of 1933 Geological survey of the Shetland islands, see Lyall, Hugh MacDiarmid's Poetry and Politics of Place, 121; MacDiarmid, 'On a Raised Beach', eds. Michael Grieve and W.R. Aitken, Complete Poems, Vol.1. Manchester: Carcanet, 1993 (1934), 422-33: 423; David Hume, An Inquiry Concerning Human Understanding, 114.

${ }^{31}$ MacDiarmid, 'On a Raised Beach', 423

${ }^{32}$ MacDiarmid, 'On a Raised Beach', 422

${ }^{33}$ James Kelman, How Late It Was, How Late. London: Secker and Warburg, 1994, 33-35.

${ }^{34}$ MacDiarmid, 'On a Raised Beach', 432-33.

${ }^{35}$ MacDiarmid, 'On a Raised Beach', 423.

${ }^{36}$ MacDiarmid, 'On a Raised Beach', 423; MacDiarmid's image of the bricole also shares a lot in common with Heidegger's notion of ' $g$ eworfenheit' (thrownness) c.f Heidegger, Martin, Being and Time. Trans. Macquarrie, John and Edward Robinson. London: Blackwell 1967 (1927), 174. It is worth noting that MacDiarmid's poem follows Heidegger's Being and Time by only seven years.

${ }^{37}$ Duns Scotus's national particularity is described in Alexander Broadie, Why Scottish Philosophy Matters. Edinburgh. Saltire Society, 2000, 24-30.

${ }^{38}$ Hugh MacDiarmid and Duncan Glen with Valda Grieve and Arthur Thompson, 'The MacDiarmids - A Conversation', in eds. Angus Calder, Glen Murray, and Alan Riach, The Raucle Tongue. Hitherto Uncollected Prose, Volume III: 1937-1978. Manchester: Carcanet, 1997 (1968), 554-569; MacDiarmid, The Company I've Kept: London: (Hutchinson and Co., 1966), 29.

${ }^{39}$ See Bryant, The Democracy of Objects.

${ }^{40}$ Gilles Deleuze and Félix Guattari, Anti-Oedipus. Trans. Brian Massumi. London: Continuum 2004 (1972), 5-10.

${ }^{41}$ MacDiarmid, 'On a Raised Beach', 423, 426; 424.

${ }^{42}$ MacDiarmid, 'On a Raised Beach', 428.

${ }^{43}$ MacDiarmid, 'On a Raised Beach' 280.

${ }^{44}$ Neal Ascherson, Stone Voices: In Search of Scotland. London: Granta, 2003 (2002), 1, 8, $26-27,30$. 
${ }^{45}$ E.g. George Mackay Brown, Brodgar Poems. Oxford: Perpetua Press, 1992; we could also compare Ian Hamilton Finlay's work with stone on mountains and gardens, and Finlay's and Morgan's acceptance of concrete poetry in the 1960s.

${ }^{46}$ Edwin Morgan, 'Slate', Sonnets from Scotland. Glasgow: Mariscat, 1984, 9.

${ }^{47}$ Morgan, 'Target', Sonnets from Scotland, 46.

${ }^{48}$ Exhibit in Museum of Scotland, described in Cohen, Stone, 189-90.

${ }^{49}$ Cordle, Late Cold War Literature and Culture, 3, 48.

${ }^{50}$ Wr. Peter Dickinson and Anna Home, dir. John Prowse, The Changes. BBC, 1975;

Dickinson, The Weathermonger. London: Collins Voyager, 2011 (1968); Dickinson,

Heartease. London: Victor Gollancz, 1969; Dickinson, The Devil's Children. London: Puffin, 1974 (1970).

${ }^{51}$ Cohen, Stone, 97.

${ }^{52}$ Wr. Bob Baker and Dave Martin, dir. Patrick Dromgoole, Derek Clark, and Terry Harding, Sky. HTV West, 1975.

${ }^{53}$ Wr. Jeremy Burnham and Trevor Roy, dir. Peter Graham Scott, Children of the Stones. HTV, 1977.

${ }^{54}$ Wr. Nigel Kneale, dir. Piers Haggard, Quatermass. Thames TV, 1979.

${ }^{55} \mathrm{Cf}$. Nick Ritchie, 'Deterrence dogma? Challenging the relevance of British nuclear weapons', International Affairs 85-1, 2009, 81-98.

${ }^{56} \mathrm{Cf}$. Michael Gardiner, The Return of England in English Literature. Basingstoke: Palgrave Macmillan, 2012. 127-137.

${ }^{57}$ Duncan Campbell, War Plan UK. London: Burnett/ Hutchison, 2015 (1983), xiv.

${ }^{58}$ Wr. and dir. Mick Jackson, QED: A Guide to Armageddon. BBC. 1982; wr. Jeremy Paxman, dir. Louise Capell, Panorama: If the Bomb Drops, BBC TV, 1980; cf.

${ }^{59}$ Owen Greene, Barry Rubin, Neil Turok, Philip Webber, Graeme Wilkinson, London After the Bomb: What a Nuclear Attack Really Means. Oxford. OUP, 1982, 62; on the impact of Threads cf. Daniel Cordle, “"That's going to happen to us. It is. Threads and the Imagination of Diaster on 1980s Television'. Journal of British Cinema and Television 10-1, 2013, 71-92; Lez Cooke, Troy Kennedy Martin. Manchester: MUP, 2007, 43.

${ }^{60}$ Wr. and dir. Humphrey Jennings, Fires Were Started. Crown Film Unit, 1943.

${ }^{61} \mathrm{Cf}$. Cordle, 'That's going to happen to us. It is', 86-87.

${ }^{62}$ Thompson, 'Protest and Survive', 34; cf. Cordle, Daniel. 'Protect/ Protest: British nuclear fiction of the 1980s'. British Journal for the History of Science, 45-4, 2012, 653-69.

${ }^{63}$ Wr. Barry Hines, dir. Mick Jackson, Threads. BBC, 1984.

${ }^{64}$ Greene et al, London After the Bomb, 55; MacDiarmid, 'On a Raised Beach', 425.

${ }^{65}$ To which might be compared Walter Benjamin's arcades, unable to hold their products. 
${ }^{66}$ Steven Connor, 'Pulverulence', 2008: http://www.stevenconnor.com/pulverulence/; cf. Cordle, Late Cold War Literature and Culture, 68; Morton, Hyperobjects, 130.

${ }^{67}$ Parikka, A Geology of Media, 85-6, 102.

${ }^{68}$ Cf. Paul Ehrlich, The Cold and the Dark: The World After Nuclear War. London 1984:

W.W. Norton, 1984. Paul Rubinson, 'Nuclear winter in science and the world, in eds.

Matthew Grant and Benjamin Ziemann, Understanding the imaginary war: Culture, Thought, and Nuclear Conflict. Manchester. MUP, 2016. 238-259.

${ }^{69}$ Owen Greene, Barry Rubin, Neil Turok, Philip Webber, Graeme Wilkinson, London After the Bomb: What a Nuclear Attack Really Means. Oxford: OUP 1982, 74

${ }^{70}$ Cf. Cabinet magazine event flyer - 'An Evening of Dust', Royal Festival Hall, 17 October 2008: http://www.cabinetmagazine.org/events/dust.php. The resulting special number is 35 , Fall 2009: http://www.cabinetmagazine.org/issues/35/index.php.

${ }^{71}$ Eugene Thacker, In the Dust of this Planet: Horror of Philosophy Vol. 1 (Alresford: Zer0, 2011), 8, 158-159; cf. also Children of the Dust. London. Bodley Head. 1985, in which mutated mindreaders make their way across nuclear ash to Stonehenge.

72 James Coughie, Edge of Darkness. London: BFI, 2007, 25, 28, 45, 60-61; Cooke, Troy Kennedy Martin, 159; Caughie. Television Drama: Realism, Modernism, and British Culture. Oxford: OUP, 2000, 7; Lez Cooke, British Television Drama: A History. London: Palgrave/ BFI, 2015, 157-58.

${ }^{73}$ Cooke, Troy Kennedy Martin, 156; Troy Kennedy Martin. Edge of Darkness. London:

Faber and Faber, 1990, viii.

${ }^{74}$ Troy Kennedy Martin, 'Opening Up the Fourth Front: Micro Drama and the Rejection of Naturalism', The James MacTaggart Lecture 1986, in ed. Bob Franklin, Television Policy: The MacTaggart Lectures (EUP, 2005), 105-112; Cooke. British Television Drama, 152-53; John Hartley, Tele-ology: Studies in Television. London: Routledge, 1992, 156.

${ }^{75}$ James Kelman, 'My Eldest', in The Good Times. London: Secker and Warburg 1998, $47-$ 50: 50 .

${ }^{76} \mathrm{cf}$. Caughie, Edge of Darkness, 19.

${ }^{77}$ See Graham Harman, The Quadruple Object. London: Zer0 Books, 2011; on withdrawing from the visual cf. Akita Mizuta Lippit, Atomic Light: Shadow Optics. Minneapolis:

University of Minnesota Press, 2005.

${ }^{78}$ Cf. Frances Ferguson, 'The Nuclear Sublime', Diacritics 14-2 Summer 1984, 4-10; cf. Caughie, Edge of Darkness, 84-85.

${ }^{79}$ Timothy Morton, Hyperobjects. Minneapolis, MN: University of Minnesota Press 2013, 1.

${ }^{80}$ Jonathan Schell, The Fate of the Earth. London: Jonathan Cape, 1982, 144.

${ }^{81}$ Ferguson, 'The Nuclear Sublime'. Diacritics 14-2. Summer 1984, 4-10: 8. 
${ }^{82}$ Caughie, Edge of Darkness, 17-18; Cohen. Stone, 176-78;

${ }^{83}$ Wr. Duncan Campbell, dir. Dennis Cosgrove, Secret Society, Ep 2, 'In Time of Darkness'. BBC TV, 1987.

${ }^{84}$ See Timothy Morton, The Ecological Thought. Cambridge MA: Harvard University Press 2012.

${ }^{85}$ A 2016 YouGov poll found only 37\% in Scotland were in favour of replacing Trident, versus 44\% across the whole of the UK. YouGov survey 14-15 July 2016.

https://d25d2506sfb94s.cloudfront.net/cumulus_uploads/document/v6sx2kxrkf/Trident_Resul ts_160715_Website.pdf 